\title{
Perihilar Bile Duct Cancer pT2 TNM
}

\section{Finding v8}

National Cancer Institute

\section{Source}

National Cancer Institute. Perihilar Bile Duct Cancer PT2 TNM Finding v8. NCI Thesaurus.

Code C134726.

Perihilar bile duct cancer with tumor invading beyond the wall of the bile duct to

surrounding adipose tissue, or tumor invading adjacent hepatic parenchyma. (from AJCC 8th Ed.) 